\title{
Quantitative Analysis of Ginsenosides Using Relative Response Factors from Ginsenoside Rf
}

\author{
Sang Myung Lee \\ Department of Chemistry \& Cosmetics, Mokwon University, Daejon, Korea
}

Corresponding author: Sang Myung Lee, Department of Chemistry \& Cosmetics, Mokwon University, 88, Doanbuk-ro, Seo-gu, Daejeon 35349, Korea

Tel.: +82428297566

Fax: +82428297561

Email: smlee@mokwon.ac.kr

\section{Received September 5, 2017}

Revised January 30, 2018

Accepted February 14, 2018

Published June 30, 2018

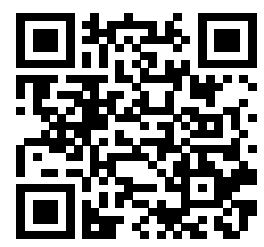

\begin{abstract}
Purpose: To establish a simple and accurate quantitative method for analyzing ginsenosides, a functional material used in the cosmetics industry, the relative response factors of the high performance liquid chromatography (HPLC) signals of each ginsenoside were analyzed and compared to the ginsenoside Rf. Methods: The relative response factor for the simultaneous analysis of 11 species of ginsenosides, including ginsenoside Rf, was determined, and their quantitative validity was examined. The concentrations of ginsenosides contained in samples of red ginseng were derived by an external standard method from the calibration curve of a standard solution prepared from the 11 species of ginsenosides. The relative response factors were calculated from the concentrations of ginsenosides in the 58 red ginseng samples. Results: The relative response factors $\left(k_{i / / f t}\right)$ of each ginsenoside relative to ginsenoside $\mathrm{Rf}$, which is thermally stable and considered valid as a reference for relative response, are as follows: Rg1 (1.07), Re (1.26), Rh1 (0.83), Rg2 (1.50), Rb1 (1.51), Rc (1.51), Rb2 (1.45), Rd (1.22), Rg3 (S; 1.02), and Rg3 ( $R ; 0.95)$. In addition, the concentration of each ginsenoside converted by their relative response factor $\left(k_{i / R+}\right.$ was quantitatively consistent with the concentration analyzed by the external standard method. Conclusion: Using quantitatively wellcontrolled ginsenoside Rf as a standard, we analyzed the ginsenoside contents of 11 kinds of ginsenosides samples. The exact contents of ginsenoside Rf in ginseng samples were determined by an external standard method. The concentrations of the 10 ginsenosides Rg1, Re, Rg2, Rh1, Rb1, Rc, Rb2, Rd, Rg3 (S), and Rg3 (R) were determined by converting their relative response factors $\left(k_{i / f r}\right)$.
\end{abstract}

Keywords: Panax ginseng, HPLC, Ginsenoside Rf, Relative response factor, Quantitative analysis

\section{Introduction}

고려인삼(Panax ginseng C. A. Meyer)은 한국, 중국, 일본 등 동아시아 지역에서 가장 빈번하게 사용하는 한약재 중의 하 나로써, 그의 산업적 가치가 대단히 높은 대표적인 식물유래 뿌 리류 생약재이다. 두릅나무과(Aralliaceae)에 속하는 인삼속 (Panax) 식물은 전 세계에 6종이 분포되어 있으며 그 중 고려인 삼은 미국삼(Panax quinquefolius. L.)과 아울러 인삼속의 대표 종이라 할 수 있다(Christensen, 2009). 특히 인삼(ginseng)이 라는 명칭은 고려인삼의 학명에만 표기되고 있으며 일반적으로 피로회복, 면역력개선 등 만병통치약(Panax)으로서 무릇 인삼 (ginseng)이라 함은 고려인삼을 의미한다. 인삼은 또한 화장품 원료 기준에 수재되어 있는 대표적인 천연 화장품 원료이다. 한 국특허정보원 자료에 의하면 인삼을 함유한 화장료는 제형에 관 계없이 다양하게 이용되고 있으며 피부개선, 노화방지, 미백 등 의 다양한 효과를 함께 나타나는 것으로 밝혀져 있다. 화장품 원 료로서 가장 많이 이용하는 인삼종은 고려인삼이며 전체의 $74 \%$ 가량이 인삼뿌리 추출물과 그 추출물에서 분리해낸 다당체, 사포 닌 등을 이용하고 있다. 인삼의 화장품 원료 특허출원을 연도별 로 살펴보면 1996년부터 현재까지의 출원 건수가 전체의 절반을 차지하여 최근 들어 인삼 함유 화장품에 관한 연구에 관심이 집 중된다는 사실을 확인할 수 있다. 
인삼속 식물의 특이성분으로서 진세노사이드는 흔히 인삼 사 포닌이라 부르는데 담마란계 테르페노이드에 다양한 종류의 당 이 결합된 배당체 화합물이다. 진세노사이드를 원료로 한 화장품 은 소망화장품의 $\mathrm{Rg} 2$ 가 대표적인 예이며 동인비, 랑 등 인삼공 사에서 개발된 화장품에는 기본적으로 홍삼 추출물이 함유되어 있다. 화장품 기능성으로서의 인삼의 유효성분 역시 진세노사이 드로 알려져 있으며 이에 대한 연구가 다양하게 이루어져 왔다. Ginsenoside $\mathrm{Rd}$ 로부터 유래된 희귀 진세노사이드와 트리올계 진세노사이드 전환체는 피부주름에 관련된 생화학적 지표를 개 선시킨다는 최근의 연구결과가 있다(Lee et al., 2013b; Lee et al., 2015). 또한 미생물로 전환된 ginsenoside F2, compound $\mathrm{K}$ 는 피부주름개선 활성지표인 matrix metalloproteinase-1 (MMP-1)의 활성을 억제하여(Min et al., 2015), 화장품 기 능성 효능지표로서 주목되고 있다. 특히 주종 사포닌으로서 ginsenoside $\mathrm{Rb} 2$ 는 피부의 콜라겐 생합성을 촉진하고 $\mathrm{MMP}-1$ 의 활성을 억제하여(Kim et al., 2007), 피부미용에 중요한 역 할을 하는 화학성분 임이 밝혀져 있다.

진세노사이드는 protopanaxadiol과 protopanaxatriol로 크 게 구분되며 protopanaxdiol은 ginsenoside $\mathrm{Rb} 1, \mathrm{Rc}, \mathrm{Rd}$ 등이 존재하며 protopanaxtriold은 ginsenoside Rg1, Re, Rf, Rg2, Rh1 등이 존재한다(Christensen, 2009; Court, 2000). 이상 언급한 화합물은 일반적으로 인삼 및 홍삼의 주종 사포닌(major saponin)으로 취급 하는 반면 홍삼에서 특이적으로 발견되는 전 환 사포닌은 미량 사포닌(minor saponin)으로 취급한다(Court, 2000). 홍삼은 인삼을 가열 건조하는 가공공정을 거치므로 홍 삼 특이 사포닌이 발견되는데 ginsenoside Rg3가 대표적이다. Rg3는 protopanaxdiol계에 속하는 주종 사포닌의 열변성 물질 이며, 이는 다시 구조이성질체로서 산화되어 ginsenoside Rg5, $\mathrm{Rk} 1, \mathrm{Rz} 1$ 로 전환된다(Lee et al., 2009). Protopanaxtriol의 변성은 주종 사포닌에 있어서 비배당부의 다양성으로 인하여 각 각의 독특한 전환 사포닌을 생성한다(Lee, 2014a). 인삼을 증 숙, 건조한 홍삼을 포함한 인삼 속 식물은 50 종 이상의 다양한 진세노사이드가 함유되어 있다(Christensen, 2009). 진세노사 이드들 중 일부는 인삼의 가열공정으로부터 동반되는 다양한 열 화학적 변화에 의해서만 생성되는 경우가 있으며 이러한 열화학 적 생성물은 인삼 원료 및 제품의 특성을 결정하는데 중요한 지 표가 된다. 따라서 인삼 원료의 품질관리 지표성분으로서 규정 된 ginsenoside $\mathrm{Rg} 1, \mathrm{Rb} 1$ 및 $\mathrm{Rg} 3$ 뿐만 아니라 다양한 종류의 사포닌(ginsenoside $\mathrm{Rg} 1$, Re, Rf. Rg2, Rh1, Rb1, Rc, Rb2, $\mathrm{Rd}, \mathrm{Rg} 3(\mathrm{~S}), \mathrm{Rg} 3(\mathrm{R}))$ 의 함량 분석이 동시에 이루어지고 있으 며 이러한 함량 자료는 인삼제품 제조공정에서 중요한 지표로 사 용되고 있다(Kim et al., 2013). 인삼 사포닌의 정량분석에 있 어서 가장 큰 문제는 각 개별 진세노사이드는 보관시간이나 보 관방법에 따른 화학적 불안정성과 함수율의 변화로 인하여 표준
물질을 정량적으로 관리하기 어렵다는 것이다. 일반적으로 동일 한 분석조건에서 표준물질 관리체계의 부정확성으로 인하여 동 일한 시료임에도 불구하고 홍삼 또는 인삼 시료에서 각 진세노사 이드의 함량편차가 크게 나는 현상이 빈번하게 발생함으로써 인 삼, 홍삼에 있어서 다양한 진세노사이드의 함량을 정량적으로 정 확하게 분석하는데 많은 제약이 따른다. 따라서 인삼의 중요 화 학성분인 다양한 진세노사이드의 정확한 함량연구를 위하여 간 편하고 안정적인 표준물질 관리방법의 도입이 절실히 요구된다. 기존의 보고에 의하면 인삼의 품질보증 지표성분으로 사용하는 ginsenoside Rg1 및 Rb1에 대하여 Kim et al. (2010)은 ISO 가이드라인에 의한 인증표준물질(certified reference material, $\mathrm{CRM}$ )을 발행한 바가 있다. 그러나 1차 표준물질(primary reference material, PRM)의 화학적 안정성 문제로 인증물질의 유효기간이 제한적이었으며 인증표준물질의 유효기간 만료 후 2017년 현재 진세노사이드 표준물질의 관리체계에 있어서 표준 물질의 소급성은 제조사의 제품 명세서에 근거하고 있는 상황이 다. 그러나 표준물질의 제조사와 사용자의 관리정도에 따라서 표 준물질의 순도는 가변적이며 이에 따른 함량 결과의 정확도에 대 한 신빙성이 감소되고 있는 실정이다.

본 연구의 목적은 화장품 원료로서 사용되는 인삼 또는 홍 삼 원재료 및 그의 추출물에 있어서 진세노사이드의 함량분 석 지표 성분관리를 간소화하여 안정적이면서도 정확한 정량법 을 제시하기 위함이다. 즉, 다른 진세노사이드에 비하여 화학적 으로 안정하며 고려인삼에 특이적으로 존재하는 ginsenoside Rf (Lee, 2014b; Lee et al., 2013a)를 기준물질로 선정하 고, ginsenoside Rf에 대한 각 진세노사이드의 상대감응인자 (relative response factor)를 이용하여 ginsenoside $\operatorname{Rg} 1$ 등 10 종의 진세노사이드 함량을 동시에 분석하는 방법을 제공하 고자 하는 것이다. 구체적으로는 인삼의 진세노사이드의 함 량을 고속 액체크로마토그래피(high performance liquid chromatography, $\mathrm{HPLC}$ 로 분석할 때 정량적으로 잘 관리되 어진 ginsenoside $\mathrm{Rf}$ 를 표준물질로 선택하여 각 인삼시료에 함 유된 ginsenoside $\mathrm{Rf}$ 의 정확한 함량을 분석한 후 이에 대한 개 별 진세노사이드(ginsenoside $\mathrm{Rg} 1, \mathrm{Re}, \mathrm{Rg} 2, \mathrm{Rh} 1, \mathrm{Rb} 1, \mathrm{Rc}$, $\mathrm{Rb} 2, \mathrm{Rd}, \mathrm{Rg} 3(\mathrm{~S}), \mathrm{Rg} 3(\mathrm{R}))$ 의 상대감응인자를 환산함으로써 ginsenoside $\mathrm{Rf}$ 이외에 10종 진세노사이드의 표준물질에 대한 별도의 정량적 관리체계를 통하지 않고 인삼 또는 홍삼 화장품 원료에 함유된 11 종의 진세노사이드의 함량을 동시에 정확하게 분석하는 방법을 제시하고자 한다.

\section{Methods}

\section{1. 실험재료}


실험에 사용된 홍삼시료는 한국인삼공사, 금산인삼조합, 자 연의길 등 국내 인삼 제조기업에서 제공받았다. 제조번호가 다 른 58 종의 홍삼 분말제품을 4항에 제시된 시료 전처리 방법으 로 58 개의 홍삼 분말시료로 제조하고 이를 ultra performance liquid chromatography (UPLC)로 11종의 진세노사이드 함 량 분석하여 상대감응인자를 구하는 용도로 사용하였다. 제조 번호가 다른 14 종의 홍삼정 제품은 4 항에 제시된 시료 전처리 방법으로 14 종의 홍삼 추출물 농축액 시료를 제조하였고 이는 HPLC로 분석하여 11 종의 진세노사이드에 대한 외부표준물질법 과 상대감응인자법에 의하여 도출된 함량 결과의 차이를 비교하 는 목적으로 사용하였다. 사용하고 남은 시료는 밀봉하여 본교 실험실 냉동고에 보관하였다. 외부 표준물질로서 사용된 10 종 의 진세노사이드(ginsenoside Rg1, Re, Rh1, Rg2, Rb1, Rc, Rb2, Rd, Rg3 (S), Rg3 (R); Ambo Institute, Korea)는 진공 오븐(VH-DD-64; LAB House, Korea)에서 건조하여 사용하 였다.

\section{2. 시약 및 기기}

실험에 사용한 크로마토그래피 기기는 Waters ACQUITY UPLC system (Waters, USA)을 사용하였으며 이에 사용된 분 석 컬럼은 ODS column (ACQUITY UPLC BEH C18 column, $100 \mathrm{~mm} \times 2.1 \mathrm{~mm}, 1.7 \mu \mathrm{m}$; Waters, USA)을 사용하였다. 또 한 기기의 종류 및 성능이 함량분석 결과 값에 미치는 영향을 확 인하기 위하여 독립된 분석기기로서 Shimadzu HPLC (LC10AT vp Pump, SCL-10A vp System controller, SPD$10 \mathrm{AV}$ UV/vis Detector; Shimadzu, Japan)를 사용하였다. HPLC를 이용한 함량분석에서는 C8 column (SunFire C8, 4.6 $\mathrm{cm} \times 7.5 \mathrm{~cm}, 3.5 \mu \mathrm{m}$; Waters, USA)을 사용하였다. 이동상으 로 사용한 유기용매는 acetonitrile (AcCN; J.T. Baker, USA) 을 구입하여 사용하였고, 증류수는 Mili-Q system (Millipore, $\mathrm{USA})$ 으로 증류한 $18 \mathrm{M} \Omega / \mathrm{cm}$ 이상의 탈이온수를 사용하였다. 외부표준물질의 정밀한 무게 측정을 위하여 화학용 정밀저울 (XS105DU; Mettler Toledo, Swiss)을 사용하였으며 0.001 $\mathrm{mg}$ 까지 측정하였다. 홍삼시료의 무게는 CAY 220 (CAS, Korea)를 사용하여 $0.01 \mathrm{mg}$ 까지 정밀하게 측정하였다.

\section{3. 외부표준물질법을 위한 11 종 ginsenoside 표준용액 제조}

약 $20 \mathrm{mg}$ 의 ginsenoside Rg1, Re, Rf, Rg2, Rh1, Rb1, $\mathrm{Rc}, \mathrm{Rb} 2, \mathrm{Rd}, \mathrm{Rg} 3(\mathrm{~S}), \mathrm{Rg} 3(\mathrm{R})$ 을 $70^{\circ} \mathrm{C}$ 에서 $0.1 \mathrm{Mpa}$ 이하로 감압한 진공건조기에서 $20 \mathrm{~h}$ 건조함으로써 수분을 최대한 제 거한 후 밀봉하여 표준물질로 사용하였다. 각 표준물질의 전체 량을 밀봉된 상태로 정밀하게 무게를 달고 신속하게 5-10 mg 에 해당하는 표준물질을 들어낸 후 다시 밀봉한 후 전체량의 무 게를 정밀하게 달아 들어낸 무게를 환산하여 이를 표준물질의
분취한 무게로 하였다. 정밀하게 무게를 측정한 11 종의 표준 물질은 $100 \mathrm{~mL}$ 의 메탄올에 정량적으로 용해시키고 이를 보관 용액으로 하였다. 보관용액은 검량선 작성을 위하여 일정 농도 로 희석하여 표준용액으로 사용하였다. 각 진세노사이드의 직 선범위는 기존에 보고된 분석법(Park et al., 2013; In et al., 2012)에 의하여 제시된 분석 유효성 자료에 의하여 정의되어 있 으므로 직선범위 내에서 단일 농도로 하였으며 각 농도의 조성 은 홍삼시료의 일반적 함량에 근거하여 조정하여 최종 농도를 ginsenoside Rg1 101.1 $\mu \mathrm{g} / \mathrm{mL}$; Re $51.0 \mu \mathrm{g} / \mathrm{mL}$; Rf 35.9 $\mu \mathrm{g} / \mathrm{mL}$; Rh1 $32.2 \mu \mathrm{g} / \mathrm{mL}$; Rg2 $35.5 \mu \mathrm{g} / \mathrm{mL}$; Rb1 132.2 $\mu \mathrm{g} / \mathrm{mL}$; Rc $36.3 \mu \mathrm{g} / \mathrm{mL}$; Rb2 $37.8 \mu \mathrm{g} / \mathrm{mL}$; Rd $35.4 \mu \mathrm{g} /$ $\mathrm{mL}$; Rg3 (S) $54.5 \mu \mathrm{g} / \mathrm{mL}$; Rg3 (R) $29.2 \mu \mathrm{g} / \mathrm{mL}$ 로 희석하여 외부 표준물질의 표준용액으로 사용하였다. 각 농도의 소수점 첫째 자리 이하는 주어진 분석법의 검량한계농도를 감안하여 처 리하였다.

\section{4. 시료 전처리}

58 종의 홍삼분말의 시료 전처리는 보유한 홍삼분말 $5 \mathrm{~g}$ 에 해 당하는 양을 $0.01 \mathrm{mg}$ 까지 정밀하게 단 후 메탄올 $(70 \%, 10 \mathrm{~mL})$ 을 가하고 $30 \mathrm{~min}$ 간 초음파 추출(SD-80H; MUJGAE, Korea) 하여 $3000 \mathrm{rpm}$ 에서 $10 \mathrm{~min}$ 간 원심분리 한 후 상징액을 0.25 $\mu \mathrm{m}$ 막여과기로 $1 \mathrm{~mL}$ 여과하여 홍삼분말 시료용액으로 하였다. 14 종의 홍삼 추출물 농축액 시료 전처리는 구입한 각 홍삼 농축 액으로부터 $2 \mathrm{~g}$ 에 해당하는 시료를 $0.01 \mathrm{mg}$ 까지 정밀하게 달아 $50 \mathrm{~mL}$ 의 비커에 옮기고 증류수 적당량으로 완전히 용해한 후 $50 \mathrm{~mL}$ 의 부피플라스크에 정량적으로 옮긴 후 증류수로 표선을 채운 후 $0.25 \mu \mathrm{m}$ 막여과기로 약 $1 \mathrm{~mL}$ 여과하여 홍삼 추출물 농 축액 시료로 사용하였다(Park et al., 2013; In et al., 2012).

\section{5. 진세노사이드의 UPLC 분석조건}

Ginsenoside Rf에 대한 각 진세노사이드의 상대감응인자 를 도출하기 위하여 58 종의 홍삼분말 시료에 대하여 Waters ACQUITY UPLC system을 이용하여 11종 진세노사이드 표준 용액을 사용한 외부표준법으로 각 시료의 진세노사이드 함량을 분석하였다. 정량분석에 사용한 칼럼은 ACQUITY UPLC BEH $\mathrm{C} 18$ 이며 컬럼의 온도는 $40^{\circ} \mathrm{C}$ 로 유지하였으며, 이동상은 다음 의 두 가지 용매계로서 농도 기울기법을 사용하였다. 이동상 $\mathrm{A}$ : 증류수, 이동상 B: acetonitrile, 이동상의 농도기울기: 0-0.5 $\min (15 \% \mathrm{~B}), 14.5 \min (32 \% \mathrm{~B}), 18.5(38 \% \mathrm{~B}), 24.0 \mathrm{~min}$ (43\% B), $27.0 \mathrm{~min}(55 \% \mathrm{~B}), 27.0-31.0(55 \% \mathrm{~B}), 35 \mathrm{~min}$ $(70 \% \mathrm{~B}), 38.0 \mathrm{~min}(90 \% \mathrm{~B}), 38.1 \mathrm{~min}(15 \% \mathrm{~B})$. 이동상의 유 속은 전 시간에 걸쳐서 $0.6 \mathrm{~mL} / \mathrm{min}$ 의 속도로 하였으며 시료 주 입량은 $2.0 \mu \mathrm{L}$ 로 하였다. 자외선 검출기는 $203 \mathrm{~nm}$ 에 고정하여 검출하였다. 


\section{6. 진세노사이드의 HPLC 분석조건}

각 인삼시료에 함유한 진세노사이드 11 종의 함량분석에 있어 서 UPLC와 HPLC 상대감응인자에 의한 환산함량의 일관성을 관찰하기 위하여 홍삼 추출물 농축액 시료를 $\mathrm{HPLC}$ 로 분석하였 다. 이동상은 다음의 두 가지 용매계로 농도기울기법을 사용하였 다. 이동상 $\mathrm{A}$ : 증류수, $\mathrm{B}$ : acetonitrile, 이동상의 농도기울기: $17-18 \%$ B (0-10 min), 18-24\% B (10-15 min), 24-27\% B (15-27 min), 27-35\% B (27-35 min), 35-37\% B (35-45 $\min$, $37-45 \% \mathrm{~B}$ (45-50 $\mathrm{min})$ 이며, 이때 이동상의 유속은 전 시간에 걸쳐서 $1.6 \mathrm{~mL} / \mathrm{min}$ 의 속도로 하였으며 시료 주입량은 $10 \mu \mathrm{L}$ 로 하였다. 11종의 진세노사이드는 $203 \mathrm{~nm}$ 에서 검출하였 다.

\section{7. 상대감응인자 $\left(k_{i}\right)$ 와 함량 계산}

외부표준물질법에 의하여 58개의 홍삼분말 시료에 포함된 11 종 진세노사이드의 함량을 정밀하게 분석한 결과로부터 대표 적인 3 종 진세노사이드의 상대감응인자 $\left(k_{i / R g I, R f, R b I}\right)$ 들을 구하 였다. 즉, UPLC를 이용하여 함량이 정확하게 분석된 자료에서 ginsenoside Rg1, Rf, Rb1 3종 중 하나를 선택, 아래 식으로 각 진세노사이드의 상대감응인자 $\left(k_{i}\right)$ 를 구하고 10 종의 각 진세노 사이드 농도 $\left(c_{i}\right)$ 를 구하였다.

$$
\begin{aligned}
& k_{i / R f}=\frac{c_{i} \times A_{R f}}{c_{R f} \times A_{i}}, \quad c_{i}=c_{R f} \times k_{i / R f} \times \frac{A_{i}}{A_{R f}} \\
& k_{i / R g 1}=\frac{c_{i} \times A_{R g 1}}{c_{R g 1} \times A_{i}}, \quad c_{i}=c_{R g 1} \times k_{i / R g 1} \times \frac{A_{i}}{A_{R g 1}} \\
& k_{i / R b 1}=\frac{c_{i} \times A_{R b 1}}{c_{R b 1} \times A_{i}}, \quad c_{i}=c_{R b 1} \times k_{i / R b 1} \times \frac{A_{i}}{A_{R b 1}}
\end{aligned}
$$

위의 식에서 $k$ 는 각 진세노사이드의 내부표준물질에 대한 상 대감응인자, $i$ 는 진세노사이드의 종류, $c$ 는 농도 $(\mu \mathrm{g} / \mathrm{mL}), A$ 는 해당 진세노사이드 피크의 면적을 표시한다.

\section{Results and Discussion}

\section{Ginsenoside Rg1, Rb1, Rf에 대한 11종 진세노사이드의 상대 감응인자}

기준 진세노사이드(ginsenoside Rg1, Rb1 또는 Rf)에 대 한 상대감응인자를 이용하여 각 홍삼시료에 함유된 11 종 진 세노사이드 함량을 구하는 방법의 타당성을 검토하기 위하여 ginsenoside Rf, Rg1, Rb1에 대한 각 진세노사이드의 상대감응 인자를 구하였다. 이를 위하여 58 종의 홍삼분말 시료가 함유하고 있는 11종 진세노사이드 함량을 UPLC 크로마토그래피를 이용하 여 외부표준물질법으로 정확하게 구하였다. Table 1 에 제시된 $k_{i}$ 값은 58 종 홍삼분말 시료로부터 구한 11종 진세노사이드의 농도 와 피크면적을 ginsenoside Rf, Rg1, Rb1의 피크면적과 농도로 부터 환산한 상대감응인자이다. 58 종 홍삼분말 시료로부터 환산 된 각 진세노사이드의 평균 감응인자를 $k_{i / R g}, k_{i / R f}$ 및 $k_{i / R b 1}$ 으로 표시하였으며 각 시료가 함유한 11종 진세노사이드의 기준물질 (ginsenoside Rg1, Rb1 또는 Rf)에 대한 상대감응인자의 정밀 성은 58 종의 홍삼분말 시료 분석에 의한 각 진세노사이드의 $k_{i}$ 값의 표준편차(standard deviation, $\mathrm{SD}$ )와 평균값에 대한 상대 표준편차의 백분율(percentage of relative standard deviation, $\mathrm{RSD} \%$ 로 표시하였다. 각 성분피크의 면적이 정확하게 측정하였 을 때 이론적으로 상대감응도의 편차는 존재하지 않을 것이다. 따라서 Table 1 에 제시된 $k_{i}$ 의 표준편차 발생원인은 각 시료의 외부표준법에 의한 함량분석 과정에서 발생하는 오차의 원인 중 각 성분피크의 면적측정에 대한 정밀성의 차이로 인한 것이 가장

\begin{tabular}{|c|c|c|c|c|c|c|c|c|c|c|c|c|}
\hline & & Rg1 & $\mathrm{Re}$ & $\mathrm{Rf}$ & $\mathrm{Rh} 1$ & Rg2 & $\mathrm{Rb} 1$ & $\mathrm{Rc}$ & $\mathrm{Rb} 2$ & $\mathrm{Rd}$ & Rg3 (S) & Rg3 (R) \\
\hline \multirow{3}{*}{$k_{i / R f}$} & $M$ & 1.07 & 1.29 & & 0.83 & 1.50 & 1.51 & 1.51 & 1.45 & 1.22 & 1.02 & 0.95 \\
\hline & SD & 0.02 & 0.03 & & 0.02 & 0.02 & 0.02 & 0.02 & 0.03 & 0.02 & 0.03 & 0.05 \\
\hline & RSD (\%) & 1.61 & 2.49 & & 1.85 & 1.18 & 1.18 & 1.38 & 1.78 & 1.34 & 3.23 & 4.96 \\
\hline \multirow{3}{*}{$k_{i / R g 1}$} & $\mathrm{M}$ & & 1.21 & 0.94 & 0.78 & 1.41 & 1.42 & 1.42 & 1.36 & 1.15 & 0.95 & 0.89 \\
\hline & SD & & 0.02 & 0.01 & 0.01 & 0.03 & 0.01 & 0.02 & 0.02 & 0.01 & 0.02 & 0.04 \\
\hline & RSD (\%) & & 1.92 & 1.58 & 1.63 & 1.98 & 0.95 & 1.58 & 1.69 & 1.30 & 2.62 & 4.68 \\
\hline \multirow{3}{*}{$k_{i / R B 1}$} & $M$ & 0.71 & 0.86 & 0.66 & 0.55 & 1.00 & & 1.00 & 0.96 & 0.81 & 0.67 & 0.76 \\
\hline & SD & 0.01 & 0.02 & 0.01 & 0.01 & 0.01 & & 0.01 & 0.01 & 0.01 & 0.02 & 0.15 \\
\hline & RSD (\%) & 0.96 & 1.64 & 1.19 & 1.27 & 1.35 & & 1.05 & 1.09 & 1.09 & 2.53 & 19.93 \\
\hline
\end{tabular}
큰 원인으로 판단되며 $k_{i}$ 값의 정밀성의 부재로 인한 결과는 아닌

Table 1. Relative response factors of the 11 ginsenosides derived from the analysis of $\mathbf{5 8}$ samples of red ginseng powder

M, mean; SD, standard deviation ( $n=58$ ); RSD, relative standard deviation, percentage of SD/M; $k_{i}$, relative response of each ginsenoside from Rf, Rg1, and Rb1. 
Table 2. Relative response factors of $\mathbf{1 0}$ ginsenosides against the reference material ginsenoside $\mathbf{R f}$

\begin{tabular}{lcccccccccc}
\hline Ginsenoside & Rg1 & Re & Rh1 & Rg2 & Rb1 & Rc & Rb2 & Rd & Rg3 (S) & Rg3 (R) \\
${ }^{1} K_{i / R f}$ & 1.07 & 1.29 & 0.83 & 1.50 & 1.51 & 1.51 & 1.45 & 1.22 & 1.02 & 0.95 \\
${ }^{2} K_{i / R f}$ & 1.07 & 1.30 & 0.84 & 1.48 & 1.53 & 1.55 & 1.44 & 1.21 & 1.02 & 0.95 \\
${ }^{3} K_{i / R f}$ & 1.06 & 1.29 & 0.85 & 1.49 & 1.51 & 1.51 & 1.45 & 1.21 & 1.01 & 0.93 \\
\hline
\end{tabular}

${ }^{1}$ Mean of the relative response factor from 58 red ginseng samples by UPLC.

${ }^{2}$ Relative response factor calculated from standard solution of 11 ginsenosides by UPLC.

${ }^{3}$ Relative response factor calculated from standard solution of 11 ginsenosides by HPLC.

UPLC, ultra performance liquid chromatography; HPLC, high performance liquid chromatography.

Table 3. Comparison between the contents from relative response factor and external standard methods

\begin{tabular}{|c|c|c|c|c|c|c|c|c|c|c|c|c|}
\hline Sam & Conc & Rg1 & $\mathrm{Re}$ & $\mathrm{Rf}$ & $\mathrm{Rh} 1$ & Rg2 & $\mathrm{Rb} 1$ & $\mathrm{Rc}$ & $\mathrm{Rb} 2$ & $\mathrm{Rd}$ & Rg3 (S) & Rg3 (R) \\
\hline \multirow{2}{*}{1} & EC & 46.7 & 52.6 & 30.8 & 35.3 & 76.0 & 242 & 108 & 89.5 & 45.6 & 29.5 & 18.8 \\
\hline & $\mathrm{RC}$ & 46.9 & 51.9 & & 33.3 & 73.0 & 237 & 93.1 & 88.2 & 45.9 & 30.0 & 18.9 \\
\hline \multirow{2}{*}{2} & EC & 132 & 59.5 & 46.5 & 44.6 & 67.2 & 204 & 56.0 & 63.5 & 53.5 & 89.5 & 54.0 \\
\hline & $\mathrm{RC}$ & 144 & 68.1 & & 43.9 & 67.0 & 208 & 57.1 & 64.7 & 54.4 & 95.3 & 53.8 \\
\hline \multirow{2}{*}{3} & EC & 130 & 64.2 & 48.1 & 46.5 & 67.8 & 204 & 51.8 & 63.2 & 51.2 & nd & nd \\
\hline & $\mathrm{RC}$ & 143 & 73.5 & & 45.7 & 67.0 & 208 & 52.8 & 64.4 & 52.0 & nd & nd \\
\hline \multirow{2}{*}{4} & EC & 162 & 65.0 & 46.5 & 44.6 & 69.0 & 203 & 56.0 & 63.5 & 53.5 & 89.5 & 54.0 \\
\hline & $\mathrm{RC}$ & 175 & 74.4 & & 43.9 & 66.0 & 208 & 57.1 & 64.7 & 54.4 & 95.3 & 53.8 \\
\hline \multirow{2}{*}{5} & EC & 95.8 & 113 & 62.8 & 32.8 & 85.7 & 443 & 201 & 162 & 97.7 & 63.5 & 42.9 \\
\hline & $\mathrm{RC}$ & 101 & 118 & & 31.1 & 88.0 & 473 & 199 & 175 & 106 & 69.0 & 45.5 \\
\hline \multirow{2}{*}{6} & EC & 75.9 & 88.1 & 50.8 & 29.7 & 75.5 & 152 & 71.6 & 21.1 & 12.1 & 50.9 & 30.5 \\
\hline & $\mathrm{RC}$ & 79.8 & 91.5 & & 28.1 & 83.5 & 162 & 71.1 & 22.8 & 13.1 & 55.3 & 32.4 \\
\hline \multirow{2}{*}{7} & EC & 59.5 & 74.2 & 43.8 & 24.5 & 69.0 & 307 & 142 & 118 & 76.1 & 48.6 & 30.3 \\
\hline & $\mathrm{RC}$ & 62.5 & 77.1 & & 23.2 & 75.0 & 328 & 141 & 128 & 82.2 & 52.8 & 32.2 \\
\hline \multirow{2}{*}{8} & EC & 51.6 & 67.5 & 36.1 & 19.7 & 57.0 & 257 & 123 & 112 & 65.9 & 36.7 & 22.8 \\
\hline & $\mathrm{RC}$ & 54.2 & 70.1 & & 18.7 & 60.0 & 276 & 122 & 121 & 71.2 & 39.9 & 24.2 \\
\hline \multirow{2}{*}{9} & EC & 50.4 & 63.6 & 34.9 & 19.0 & 55.0 & 249 & 119 & 103 & 53.9 & 35.5 & 23.1 \\
\hline & $\mathrm{RC}$ & 53.0 & 66.0 & & 18.0 & 58.0 & 266 & 118 & 111 & 58.2 & 38.6 & 24.6 \\
\hline \multirow{2}{*}{10} & EC & 62.9 & 73.8 & 43.8 & 32.1 & 80.0 & 312 & 136 & 122 & 65.4 & 49.4 & 31.4 \\
\hline & $\mathrm{RC}$ & 66.1 & 76.6 & & 30.4 & 76.0 & 333 & 135 & 132 & 70.6 & 53.6 & 33.3 \\
\hline \multirow{2}{*}{11} & EC & 66.0 & 77.7 & 47.2 & 32.9 & 66.1 & 332 & 149 & 126 & 65.6 & 52.0 & 32.6 \\
\hline & $\mathrm{RC}$ & 69.4 & 80.7 & & 31.5 & 70.0 & 355 & 148 & 136 & 70.9 & 56.5 & 34.6 \\
\hline \multirow{2}{*}{12} & EC & 59.5 & 74.2 & 43.8 & 24.5 & 66.3 & 307 & 142 & 118 & 76.1 & 48.6 & 30.3 \\
\hline & $\mathrm{RC}$ & 62.5 & 77.1 & & 23.2 & 72.0 & 328 & 141 & 128 & 82.2 & 52.8 & 32.2 \\
\hline \multirow{2}{*}{13} & EC & 90.4 & 111 & 58.8 & 33.5 & 85.0 & 415 & 189 & 164 & 95.4 & 62.3 & 37.5 \\
\hline & $\mathrm{RC}$ & 95.0 & 116 & & 31.7 & 92.0 & 443 & 188 & 177 & 103.1 & 67.6 & 39.8 \\
\hline \multirow{2}{*}{14} & EC & 12.3 & 39.8 & 15.1 & 9.2 & 96.0 & 259 & 139 & 118 & 55.0 & 95.6 & 22.2 \\
\hline & $\mathrm{RC}$ & 12.9 & 41.4 & & 8.7 & 100 & 277 & 138 & 127 & 59.4 & 104.0 & 23.6 \\
\hline
\end{tabular}

Sam, 14 samples of red ginseng extracts; Conc, concentration $(\mu \mathrm{g} / \mathrm{mL})$; EC, concentration from external standard method; RC, concentration from relative response factor $\left(k_{i k f}\right)$ method; nd, no detection.

것으로 판단된다. 따라서 ginsenoside $\mathrm{Rf}$ 에 대한 ginsenoside Rg1, Re, Rh1, Rg2, Rb1, Rc, Rb2, Rd, Rg3 (S), Rg3 (R) 의 상대감응인자는 $k_{R g 1 / R f}(1.07), k_{R e / R f}(1.29), k_{R h 1 / R f}(0.83)$, $k_{R g 2 / R f}(1.50), k_{R b 1 / R f}(1.51), k_{R c / R f}(1.51), k_{R b 2 / R f}(1.45), k_{R d / R f}$ (1.22), $k_{R g 3(\mathrm{~S}) / R f}(1.02), k_{R g 3(\mathrm{R}) / R f}(0.95)$ 으로 파악되었다.

\section{2. 상대감응인자법과 외부표준물질법에 의한 함량결과 비교}

58종 홍삼분말 시료로부터 유도된 ginsenoside $\mathrm{Rf}$ 에 대 한 UPLC의 각 진세노사이드의 상대감응인자 값을 검증하기 위하여 11종 진세노사이드 표준용액을 HPLC 및 UPLC로 분석 하여 ginsenoside Rf에 대한 각 진세노사이드의 상대감응인자 
Table 4. Relative difference in ginsenoside contents by an external standard and relative response factor $\left(k_{i / R f}\right)$ method

\begin{tabular}{lcccccccccc}
\hline & Rg1 & Re & Rh1 & Rg2 & Rb1 & Rc & Rb2 & Rd & Rg3 (S) & Rg3 (R) \\
RDC (\%) & 3.49 & 2.80 & 3.29 & 5.28 & 3.59 & 4.45 & 3.79 & 3.20 & 3.24 & 2.89 \\
\hline
\end{tabular}

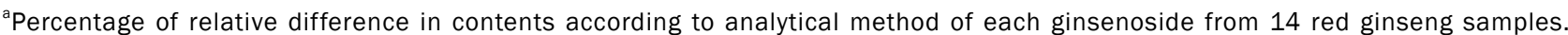
$\mathrm{RDC}(\%)=$ mean of $(\mathrm{EC}-\mathrm{RC}) / \mathrm{EC} \times 100 \%$, where $\mathrm{EC}$ is concentration from an external standard method, and RC is concentration from relative response factor $\left(k_{i k f f}\right)$ method.

의 평균값을 구하였을 때 그들 상대감응인자는 정확하게 일치하 였다(Table 2). 이 결과는 주어진 시료 전처리 방법으로 제조된 모든 홍삼 시료에 포함된 11종 진세노사이드의 농도는 검량선의 직선구간에 포함되어 있으며 따라서 상대감응인자는 각 진세노 사이드의 함량계산에 적용할 수 있음을 보여주고 있다. Table 3 은 $\mathrm{HPLC}$ 를 사용하여 14 종 홍삼 추출물 농축액 시료에 대하여 외부표준물질법에 의한 함량결과와 상대감응인자 $\left(k_{i / R f}\right)$ 에 의해 환산된 11종 진세노사이드의 함량결과를 나타낸 것이다. 각 시 료들의 진세노사이드의 함량은 시료에 따라서 개체 편차가 크게 나타나며 이는 농산물 등 식물시료에서 흔히 생기는 결과이다. 주목할 점은 외부표준물질법과 상대감응인자법의 실험결과를 비 교하였을 때 거의 동일한 결과를 보인다는 것이다. Table 4 는 $\mathrm{HPLC}$ 를 사용하여 14종 홍삼 추출물 농축액시료에 대하여 외부 표준물질법에 의한 함량결과와 상대감응인자 $\left(k_{i / R t}\right)$ 에 의해 환산 된 11종 진세노사이드의 함량결과 차이를 상대표준편차로 표시 한 것이다. 두 가지 방법으로 구한 각 진세노사이드의 함량차의 절대값에 대한 상대표준편차는 4.45-3.20\%로서 함량이 비교적 높은 진세노사이드에서 상대표준편차가 비교적 작고 함량이 상

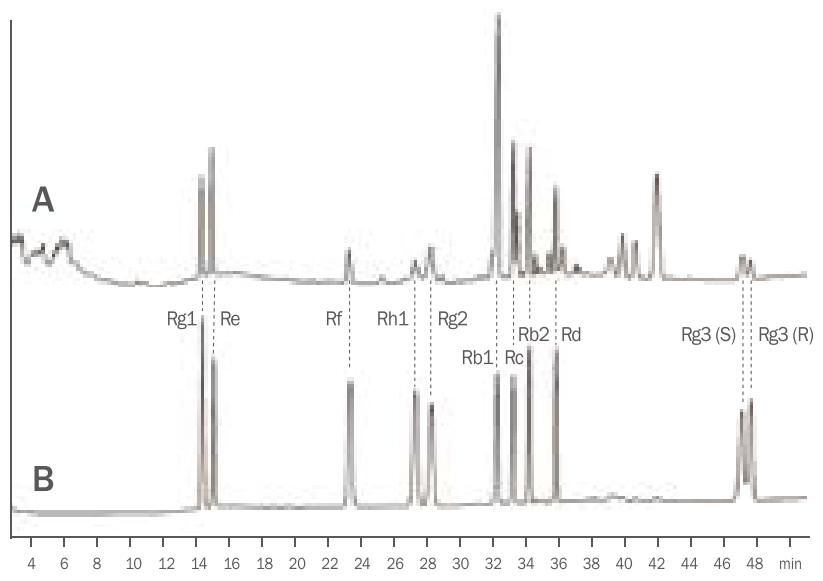

Figure 1. HPLC chromatography of ginsenosides from red ginseng extract.

(A) Representative HPLC chromatography of a sample of red ginseng extract and (B) HPLC chromatography of the standard solution comprising 11 ginsenosides. Mobile phase: $A$, Water; $B$, acetonitrile; $17 \%-18 \%$ B (0-10 min), 18\%-24\% B (10-15 min), 24\%-27\% B (15-27 min), 27\%-35\% B (27-35 min), 35\%-37\% $\mathrm{B}$ (35-45 min), 37\%-45\% B (45-50 min). Flow rate=1.6 mL/min; detection=203 $\mathrm{nm}$; column=C8 column (SunFire C8, $4.6 \mathrm{~cm} \times 7.5$ $\mathrm{cm}, 3.5 \mu \mathrm{m})$; injection volume $=10 \mu \mathrm{L}$.
대적으로 낮은 진세노사이드에서 상대표준편차가 높아지는 것으 로서 나타나지만 대체적으로 각 진세노사이드에 있어서 거의 유 사한 결과를 나타내었다. 이때 함량 편차에 영향을 주는 요인은 피크의 넓이 계산의 정밀성의 한계인 것으로 판단된다.

\section{3. 상대감응 기준물질로서의 ginsenoside Rf 변화}

상대감응 기준물질로서의 ginsenoside $\mathrm{Rf}$ 를 포함한 3 종의 진 세노사이드를 평가할 때, ginsenoside Rg1은 분석컬럼의 성능 이나 분석자의 숙련도에 의해서 인접한 ginsenoside Re가 중첩 되는 경우가 빈번하게 발생하기 때문에 이웃한 성분피크와의 분 리도에 문제가 있을 수 있다. 이러한 문제점은 ginsenoside $\mathrm{Rb} 1$ 에서도 동일하게 발생한다. ginsenoside Rb1의 피크에 인접 한 ginsenoside Rg2, Rc 등이 존재하며 이들 성분들은 분석환 경에 따라 ginsenoside $\mathrm{Rb} 1$ 의 피크에 삽입 또는 중첩 및 머무 름 시간의 섞임 등의 요인들이 발생하며 분석하는 데 있어서 여 러 가지 혼란을 야기한다. 그러나 전술한 2 개의 성분에 비하여 ginsenoside Rf는 분리도에 있어서 인접한 머무름 시간대에 존 재하는 피크가 거의 없는 것이 특징이다. 즉 역상 크로마토그래피 에 있어서 ginsenoside Rf의 분리도는 이웃한 피크에 전혀 영향 을 받지 않고 완전하게 분리된다(Figure 1). 또한 보고에 의하면 ginsenoside Rf는 화학적 안정성이 ginsenoside $\mathrm{Rg} 1, \mathrm{Rb} 1$ 에 비 하여 우월하여 인삼의 건조 또는 추출에 따르는 열에 대한 노출에 비교적 안정성을 유지하는 것으로 알려져 있다(Lee, 2014a; Lee et al., 2013b; Lee 2015). 따라서 ginsenoside Rf는 이웃한 피 크에 대한 영향이 없으며 화학적으로 안정한 성분으로서 적당한 상대감응 표준물질로서 평가할 수 있다. 따라서 외부표준물질법 에 의하여 개별 시료에서 ginsenoside $\mathrm{Rf}$ 의 함량이 결정될 경우 이를 기준물질로 하여 각 성분들의 피크면적과 ginsenoside Rf에 대한 상대감응인자 $\left(k_{i / R f}\right)$ 를 환산할 때 간편하고 안정적으로 각 성 분들의 함량을 구할 수 있을 것으로 판단된다. Ginsenoside Rf에 대한 10 종의 진세노사이드의 상대감응인자를 이용한 함량분석의 장점은 11 종의 진세노사이드 표준물질을 모두 확보하여 그들 표 준물질을 정량적으로 관리하지 않아도 된다는 것이다. 따라서 본 연구로부터 제시되는 분석법은 다른 진세노사이드 보다 상대적으 로 안정한 ginsenoside $\mathrm{Rf}$ 를 기준물질로서 내부표준물질법의 장 점을 도입한 경제적이고 정량적인 분석방법으로 평가된다. 


\section{Conclusion}

고려인삼의 특이 성분인 ginsenoside $\mathrm{Rf}$ 를 기준성분으로 하 여 이를 포함한 11 종 진세노사이드를 동시분석하기 위한 상 대감응인자를 도출하고 이의 정량적 타당성을 검토하였다. Ginsenoside Rf에 대한 ginsenoside Rg1, Re, Rh1, Rg2, $\mathrm{Rb} 1, \mathrm{Rc}, \mathrm{Rb} 2, \mathrm{Rd}, \mathrm{Rg} 3(\mathrm{~S}), \mathrm{Rg} 3(\mathrm{R})$ 의 상대감응인자는 58 종 의 시료로부터 환산하였으며 각 성분들의 상대감응인자는 $k_{R g 11}$ ${ }_{R f}(1.07), k_{R e / R f}(1.29), k_{R h 1 / R f}(0.83), k_{R g 2 / R f}(1.50), k_{R b 1 /}$ ${ }_{R f}(1.51), k_{R c / R f}(1.51), k_{R b 2 / R f}(1.45), k_{R d / R f}(1.22), k_{R g 3(S) / R f}$ $(1.02), k_{R g 3(R) / R f}(0.95)$ 이었다. 이때 시료가 함유하고 있는 각 진세노사이드의 함량은 상기한 11 종 성분들에 대하여 정밀하게 제조된 표준용액의 검량선으로부터 도출하였으며 ginsenoside $\mathrm{Rf}$ 의 함량과 피크면적 및 각 진세노사이드의 함량과 피크면적을 이용하여 상대감응인자를 도출하였다. 시료에 의하여 환산된 상 대감응인자와 표준용액으로부터 환산된 상대감응인자는 정확하 게 일치하였으며 $k_{i / R f}$ 에 의해 계산된 시료 속의 각 성분 함량은 외부표준물질법에 의하여 분석한 함량 값과 정량적으로 일치하 였다. 따라서 향후 본 논문에 제시된 11 종의 진세노사이드의 함 량을 인삼 시료로부터 분석하고자 할 때에 외부표준물질법을 이 용하여 ginsenoside $\mathrm{Rf}$ 의 함량을 구한 후 나머지 10 종의 성분 (ginsenoside Rg1, Re, Rg2, Rh1, Rb1, Rc, Rb2, Rd, Rg3 $(\mathrm{s}), \operatorname{Rg} 3(\mathrm{r}))$ 을 각 $k_{i / R f}$ 를 이용하여 환산하면 각 인삼 시료로부 터 용이하게 정량적인 함량을 구할 수 있을 것이다.

\section{References}

Court WE. Ginseng, the genus Panax. Harwood Academic Publishers, Amsterdam, pp70-74, 2000.

Christensen LP. Ginsenosides chemistry, biosynthesis, analysis, and potential health effects. Advances in Food and Nutrition Research, 55: 1-99, 2009.

In G, Ahn NG, Bae BS, Han ST, Noh KB, Kim CS. New method for simultaneous quantification of 12 ginsenosides in red ginseng powder and extract: in-house method validation. Journal of Ginseng Research, 36: 205-210, 2012.

Kim DH, Chang JK, Sohn HJ, Cho BG, Ko SR, Nho KB, Jang DS, Lee SM. Certification of a pure reference material for ginsenoside Rg1. Accreditation and Quality Assurance, 15: 81-87, 2010.

Kim HJ, Kwak IA, Kim HJ, Ahn JS, Son YB. A study on the amendment scheme of ginsenoside content standard regulation for red ginseng product in Korea. Journal of Food Hygiene and Safety, 28: 24-30, 2013.

Kim N, Koo B, Lee S, Hwang E, So S, Do J. Effect of Korean red ginseng on collagen biosynthesis and MMP-1 activity in human dermal fibroblast. Journal of Ginseng Research, 31: 86-92, 2007.

Lee SM, Shon HJ, Choi CS, Hung TM, Min BS, Bae K. Ginsenosides from heat processed ginseng. Chemical \& Pharmaceutical Bulletin, 57: 92-94, 2009.

Lee SM, Seo HK, Oh J, Na M. Updating chemical profiling of red ginseng via the elucidation of two geometric isomers of ginsenosides Rg9 and Rg10. Food Chemistry, 141: 3920-3924, 2013a.

Lee SM, Im YH, Kim SC, Choi JH, Kim JH. Anti-wrinkle effects of converted protopanaxatriol prepared from Korean red ginseng. Asian Journal of Beauty and Cosmetology, 11: 877-882, 2013b.

Lee SM. Thermal conversion pathways of ginsenosides in red ginseng processing. Natural Product Sciences, 20: 119-128, 2014a.

Lee SM. The mechanism of acid-catalyzed conversion of ginsenoside Rf and two new 25-hydroxylated ginsenosides. Phytochemistry Letters, 10: 209-214, 2014b.

Lee JH, Cho SH, Yun MY, An S, Jang HH, Lee SN, Song GY. Anti-wrinkle effect of rare ginsenosides, produced from ginsenoside Rd. Asian Journal of Beauty and Cosmetology, 13: 909-916, 2015.

Lee SM. The mass balance of protopanaxatriol ginsenoside in red ginseng process. Korean Journal of Pharmacognosy, 46: 223-228, 2015.

Min JW, Kim HJ, Joo KS, Kang HC. Isolation of Stenotrophomonas rhizopilae strain GFC09 with ginsenoside converting activity and anti-wrinkle effects of converted ginsenosides. Journal of the Society of Cosmetic Scientists of Korea, 41: 375-382, 2015.

Park HW, In G, Han ST, Lee MW, Kim SY, Kim KT, Cho BG, Han GH, Chang IM. Simultaneous determination of 30 ginsenosides in Panax ginseng preparations using ultra performance liquid chromatography. Journal of Ginseng Research, 37: 457-467, 2013. 


\section{국문초록}

\section{Ginsenoside Rf에 대한 상대감응인자를 이용한 11종 진세노사이드의 함량분석}

이상명

목원대학교 테크노과학대학 생의약화장품학과, 대전, 한국

목적: 인삼에서 화장품 기능성 물질인 진세노사이드(ginsenosides)의 간단하고 정확한 high performance liquid chromatography (HPLC) 정량분석방법을 확립하기 위하여 11종 진세노사이드의 ginsenoside Rf에 대한 상대감응인자를 분석하였다. 방법: Ginsenoside Rf에 대한 10 종 진세노사이드의 상대감응인자를 결정하고, 그 정량적 타당성을 조사하였다. 58 개 홍삼 분말시료에 함유된 진세노사이드의 농도는 정밀하게 제조된 11 종의 진세노사이드(ginsenoside Rg1, Re, Rf, Rh1, Rg2, Rb1, Rc, Rb2, Rd, Rg3 (S), Rg3 (R)) 표준용액의 검량선을 작성하여 외부 표준물질법에 의해 유도하였다. Ginsenoside Rf에 대한 10 종 진세노사이드 의 상대감응인자는 58 개의 홍삼분말시료에 포함된 각 진세노사이드 농도와 피크면적, ginsenoside Rf의 농도와 피크면적을 이용 하여 상대감응인자 환산식에 대입하여 구하였다. 결과: 열화학적으로 안정하여 상대감응 기준물질로서 타당한 것으로 인정되는 ginsenoside Rf에 대한 각 진세노사이드의 상대감응인자 $\left(k_{i / R f}\right)$ 는 58 종 홍삼 분말시료 분석에 의하여 다음과 같은 값을 나타내었다. Ginsenosides Rg1 (1.07), Re (1.29), Rh1 (0.83), Rg2 (1.50), Rb1 (1.51), Rc (1.51), Rb2 (1.45), Rd (1.22), Rg3 (S; 1.02) 및 Rg3 (R; 0.95). 또한 상대감응인자에 의해 환산된 각 진세노사이드의 농도는 외부 표준물질방법에 의해 분석된 농도와 정량적으로 일치 하였다. 결론: Ginsenoside Rg1을 포함한 11종 진세노사이드의 함량을 인삼 시료로부터 분석하고자 할 때에 우선 정량적으로 잘 관리된 ginsenoside $\mathrm{Rf}$ 를 표준물질로 이용하고 외부 표준물질법으로써 ginsenoside Rf의 정확한 함량을 구한 후 나머지 10종 성분 (ginsenoside Rg1, Re, Rg2, Rh1, Rb1, Rc, Rb2, Rd, Rg3 (S), Rg3 (R))의 함량을 각 상대감응인자 $\left(k_{i / R f}\right)$ 를 이용하여 구하면 각 인 삼 시료로부터 용이하게 정량적인 함량을 파악할 수 있다.

핵심어: 인삼, HPLC, Ginsenoside Rf, 상대감응인자, 정량분석

\section{참고문헌}

이상명, 임영호, 김석창, 최재환, 김진희. 홍삼에 함유된 프로토파낙사트리올계 전환사포닌의 피부주름 개선효과. 아시안 뷰티화장품학술지, 11: 877-882, 2013b.

이상명. 홍삼제조과정 중 파낙사트리올계 진세노사이드의 물질균형. 생약학회지, 46: 223-228, 2015.

이지현, 조수현, 윤미영, 안성관, 장현희, 이성내, 송규용. 진세노사이드 $\mathrm{Rd}$ 로부터 희귀진세노사이드의 제조 및 주름개선 효과. 아시안뷰티화장품학술지, 13: 909-916, 2015.

민진우, 김혜진, 주광식, 강희철. 사포닌 전환 활성 Stenotrophomonas rhizopilae Strain GFC09 균주의 분리 동정 및 전환 사포닌의 주름 개선 효과. 대한화장품학회지, 41: 375-382, 2015.

김호진, 곽인애, 김현정, 안종성, 손영배. 홍삼가공품의 Ginsenoside 함량 규격기준 개선방안 연구. 한국식품위생안전성 학회지, 28: 24-30, 2013. 


\section{中文摘要}

\section{用人参㿝弍Rf的相对响应因子定量分析人参㿝式}

李相明

牧圆大学生医药化妆品学科, 大田, 韩国

目的：人参皇苷是人参中的化妆品功能性物质, 为了建立简便准确的人参皇苷的 high performance liquid chromatography (HPLC) 定量分析方法，分析11种人参皇苷相对响应因子。方法: 同时分析人参皇苷Rf等11种 人参㿝苷的相对响应因子，并检测其定量效度。58个红参样品中人参皇式的含量是通过外标法从 11 种人参皇式 (ginsenoside Rg1, Re, Rf, Rh1, Rg2, Rb1, Rc, Rb2, Rd, Rg3 (S), Rg3 (R))制备的标准溶液的标准曲线中推导出来 的。相对响应因子由58种红参中的人参皇苷浓度，峰面积，人参皇苷Rf的浓度和峰面积来计算得到。结果：人 参皇苷具有热化学稳定性, 被认为是有效的相对参考物质。根据对 58 种红参粉末样品的分析, 每种人参皇苷 对人参皇苷Rf的相对响应因子 $\left(k_{i / R f}\right)$ 如下所示 : Rg1 (1.07), Re (1.26), Rh1 (0.83), Rg2 (1.50), Rb1 (1.51), Rc (1.51), Rb2 (1.45), Rd (1.22), Rg3 ( $;$; 1.02) 和Rg3 (R; 0.95)。此外, 由相对响应因子转换的每种人参㿝苷的浓 度在数量上与通过外标法分析的浓度一致。结论: 为了分析人参样品中, 包含Rg1的11种人参皇苷的含量, 首先 以定量控制好的人参皇苷Rf为参照物, 采用外标法测定人参皇苷Rf的准确含量, 然后, 利用每个相对响应因子 $\left(k_{i / R R}\right)$ 计算其余10种成分 (ginsenoside Rg1, Re, Rh1, Rg2, Rb1, Rc, Rb2, Rd, Rg3 (S), Rg3 (R)) 的含量。通过 以上方法, 从每个人参样品中, 可以容易地掌握定量含量。

关键词: 人参, 高效液相色谱法, 人参㿝式, 相对响应因子, 定量分析 
